\title{
Development of pig blastocysts in a uterine environment advanced by exogenous oestrogen*
}

\author{
G. L. Morgan $\dagger$, R. D. Geisert $\ddagger$, M. T. Zavy§, R. V. Shawley $\dagger$ and
}

A. T. Fazleabas $\uparrow$

$\dagger$ Department of Veterinary Medicine and Surgery, and $\ddagger$ Animal Science Department, Oklahoma

State University, Stillwater, OK 74078; §U.S. Department of Agriculture, ARS, El Reno, OK

73036; and $\uparrow$ Department of Obstetrics and Gynaecology, University of Illinois, Chicago, IL 60612, U.S.A.

\begin{abstract}
Summary. Routine embryo transfer techniques were used to establish recipient groups in which blastocysts were either asynchronous (blastocysts $24 \mathrm{~h}$ behind recipient uterus) or synchronous with their uterine environment. Oestradiol valerate $(5 \mathrm{mg})$ was administered on Day 11 of the recipient's cycle to stimulate release of uterine secretion in the synchronous gilts (Group SE) and one group (AE) of asynchronous gilts. The gilts in the other asynchronous group (Group AC) were injected with vehicle (sesame oil). Embryos recovered on Day 14 by hysterectomy and flushing were evaluated for morphological development.

Oestradiol treatment resulted in a failure of blastocyst development in Group AE gilts only. Recoverable oestradiol in the uterine flushings was increased in gilts in Groups AC and SE which contained elongated blastocysts. Plasmin inhibitor levels were lower in Groups AC and SE while PGF tended to be increased. Acid phosphatase activity was higher and recoverable $\mathrm{Ca}^{2+}$ was lower in Groups AE and SE. Failure of blastocyst development in Group AE is believed to have resulted from a failure to undergo trophoblastic elongation due to premature alteration of the uterine environment at a critical period of blastocyst development or from the presence of an unfavourable uterine environment for blastocyst attachment and development shortly after Day 12.
\end{abstract}

\section{Introduction}

During early pregnancy in the pig, morphologically advanced blastocysts appear to have a greater survival potential than their less developed littermates (Pope et al., 1982; Pope \& First, 1985; Wilmut et al., 1985). Considering the wide variation which can occur in morphological development (2-10 mm in diameter) between embryos within a litter on Day 12 of pregnancy (Anderson, 1978; Geisert et al., 1982b), a potential survival advantage of more advanced embryos is not surprising. Pope et al. (1982) suggested that the biochemical synthetic activity of more developed embryos may stimulate a marked alteration in the biochemical composition of the uterine luminal environment. It was in turn suggested that an altered uterine environment was embryocidal to those embryos not capable of adapting to the change in uterine secretion. Pig blastocysts have increased biochemical and physiological activity after attaining a spherical diameter of $\sim 10 \mathrm{~mm}$ on Day 11.5 of pregnancy, as shown by the onset of oestrogen synthesis (Gadsby et al., 1980; Fischer et al., 1985), polypeptide synthesis (Godkin et al., 1982), and concurrent rapid elongation of the blastocyst from a spherical to filamentous form (Geisert et al., 1982b). Geisert et al. (1982a) demonstrated

\footnotetext{
*Reprint requests to Professor R. D. Geisert.
} 
that the onset of blastocyst oestrogen synthesis was followed by a significant increase in intraluminal calcium content and a synchronized release of secretory vesicles from uterine glandular epithelial cells, resulting in radical changes in the biochemical milieu within the uterine lumen.

An unfavourable uterine environment for less developed littermates may explain a significant portion of the high $(20-40 \%)$ embryonic loss within the first 2-3 weeks of pregnancy in the pig (for review see Pope \& First, 1985). The importance of synchrony between blastocyst development and uterine environment has been demonstrated through the application of embryo transfer techniques in several species including the sheep (Rowson \& Moor, 1966), cow (Rowson et al., 1969) and pig (Polge, 1982). In these species, the most successful transfer of embryos occurs when synchrony of donor and recipient is within $24 \mathrm{~h}$. On Day 12 of pregnancy individual pig blastocysts can exhibit developmental discrepancy of more than $24 \mathrm{~h}$ from their littermates (Anderson, 1978).

Geisert et al. (1982c) indicated that oestrogen administration to gilts on Day 11 of the oestrous cycle stimulated a uterine secretory response similar to that initiated by blastocyst oestrogen synthesis. Therefore, a study was designed to determine whether pig blastocysts would develop in an environment in which endometrial secretion had been prematurely stimulated from its normal synchrony with blastocyst elongation.

\section{Materials and Methods}

Animals. Sexually mature crossbred gilts of similar age (7-8 months), weight (100-130 kg) and having exhibited at least two oestrous cycles of normal duration (18-22 days) were utilized in all experiments. Gilts were observed for oestrus twice daily $(08: 00$ and 18:00 h) in the presence of intact boars with day of onset of oestrus designated Day 0 . Gilts assigned to be bred were mated to fertile boars at the start of oestrus, and 12 and $24 \mathrm{~h}$ later.

Experimental design. Embryos were surgically recovered from donor gilts $(\mathrm{N}=12)$ on Day 5 and transferred to a Day- 5 synchronous group or one of two Day- 6 asynchronous groups $(\mathrm{N}=4$ per group), in which the uterine environment was at least $24 \mathrm{~h}$ in advance of embryonic development. Synchronous gilts received a $5 \mathrm{mg}$ intramuscular injection of oestradiol valerate (R. J. Legere \& Co., Scottsdale, AZ, U.S.A.) on Day 11 of the recipient's cycle (Group SE) while gilts in one asynchronous group received the same treatment (Group AE) and those in the second asynchronous group served as vehicle (sesame oil-treated) controls (Group AC).

Embryo survival is not affected when donor embryos are transferred $24 \mathrm{~h}$ out of synchrony with the recipient's oestrous cycle (Polge, 1982). Therefore, gilts in Group AC were expected to exhibit normal embryo development while those in Group AE would have uterine endometrial secretion stimulated in advance of the expected time of blastocyst elongation. The gilts in Group SE were to demonstrate that exogenous oestrogen treatment itself at the time of normal blastocyst elongation and oestrogen release had no detrimental effect on the development and survival of embryos.

On Day 14, all recipient gilts were ovario-hysterectomized via mid-ventral laparotomy following induction of anaesthesia with a $5 \%$ solution of thiopentone sodium (Abbott Laboratories, North Chicago, IL, U.S.A.) and maintenance on a closed circuit system of halothane (2-5\% Fluothane, Aveco Co., Inc., Fort Dodge, IA, U.S.A.) and oxygen $(1.01 / \mathrm{min})$. Embryos were recovered on Day 14 of pregnancy to allow sufficient time for transferred blastocysts to have undergone trophoblastic elongation. After removal of the uterus, each horn was flushed with $20 \mathrm{ml}$ sterile saline $(9 \mathrm{~g} \mathrm{NaCl} / \mathrm{l})$ and the flushings were examined for the presence of embryos. Embryos were visually evaluated for size, form and intactness. The saline flushing recovered was centrifuged $(12000 \mathrm{~g})$ for $20 \mathrm{~min}$ at $4^{\circ} \mathrm{C}$. The supernatant was stored at $-20^{\circ} \mathrm{C}$ until analyses could be performed.

Embryo transfer. Embryo transfer procedures were performed following induction of anaesthesia as described previously. The reproductive tract of the donor was exposed via mid-ventral laparotomy. After isolation of the oviduct, a small puncture was made into the lumen of the isthmus with a cutting needle $1.0 \mathrm{~cm}$ distal from the utero-tubal junction. A modified polyvinyl catheter with two side ports cut $1.5 \mathrm{~cm}$ from the tip was inserted into the oviduct and gently threaded $3-4 \mathrm{~cm}$ into the uterine horn. The uterine horn was clamped between finger and thumb about $20 \mathrm{~cm}$ from the uterine body while $20 \mathrm{ml}$ recovery medium, modified Dulbecco's phosphate-buffered saline (modified DPBS; Sigma Chemical Co., St Louis, MO, U.S.A.) containing $1 \%(\mathrm{v} / \mathrm{v})$ fetal calf serum was infused into the horn. The fluid was gently massaged down the horn and then back through the catheter into a sterile dish. The dish was immediately examined under a binocular microscope and embryos identified and classified (degenerate/intact and morula/blastocyst) before transfer to short-term culture medium (modified DPBS containing $10 \%(\mathrm{v} / \mathrm{v})$ fetal calf serum) in a second dish. Embryos were washed three times in the second medium at room temperature before transfer. Recipient gilts were prepared for surgery in the same manner as above. Only the tip of one uterine horn was exposed and a puncture incision was made in a manner similar to the recovery procedure. An average of 10 (range 7-13) transferable embryos were drawn into the tip of a sterile Pasteur pipette (siliconized and fire-polished) attached to a sterile glass syringe in a volume of $<0.5 \mathrm{ml}$ medium. The tip was gently passed through the puncture wound and threaded into the uterine horn for at least $4.0 \mathrm{~cm}$ whereupon the embryos were deposited. The laparotomy incision 
was closed in routine fashion. All gilts undergoing surgical procedures were injected (i.m.) with procaine penicillin $G$ (20000 i.u. $/ \mathrm{kg}$ ).

Uterine calcium analysis. Calcium ion $\left(\mathrm{Ca}^{2+}\right)$ concentrations in uterine flushings were measured with a Calcette calcium analyser (Precision Systems, Inc., Sudbury, MA, U.S.A.). The system utilized ethylene glycol tetraacetic acid for fluorometric titration of calcium in aqueous solutions (Alexander, 1971). The sensitivity of the analysis was $10^{-4} \mu \mathrm{g} / \mathrm{ml}$.

Uterine protein and acid phosphatase activity. Protein concentration in uterine flushings was determined by the method of Lowry et al. (1951). Acid phosphatase activity was determined, using $p$-nitrophenyl phosphate as the substrate, as described by Basha et al. (1979). One unit of activity was defined as the capacity to release one $\mu \mathrm{mol}$ p-nitrophenol per minute at $\mathrm{pH} 4.9$ in $0.1 \mathrm{M}$-acetate buffer.

Two-dimensional polyacrylamide gel electrophoresis ( $P A G E)$. Qualitative changes in protein collected in the uterine flushings were analysed by two-dimensional PAGE. A volume of uterine flushing containing $2 \mathrm{mg}$ protein was dialysed $\left(M_{\mathrm{r}}\right.$ cutoff $\left.\sim 3500\right)$ against several volumes of $1 \mathrm{mM}-\mathrm{Tris}-\mathrm{HCl}$ buffer (pH 8.2). After lyophilization, the dialysed uterine protein was prepared for two-dimensional PAGE by directly dissolving in $1 \mathrm{ml} 5 \mathrm{~mm}-\mathrm{K}_{2} \mathrm{CO}_{3}$ containing $9.4 \mathrm{M}$-urea, $2 \%(\mathrm{v} / \mathrm{v})$ Nonidet P-40 and $0.5 \%(\mathrm{w} / \mathrm{v})$ dithiothreitol. The PAGE was performed (300 $\mu \mathrm{g}$ protein loaded) for acidic and basic proteins according to the method described by Basha et al. (1979).

Prostaglandin $F$ analysis. Concentration of prostaglandin (PG) $\mathrm{F}$ in uterine flushings was measured by a doubleantibody radioimmunoassay using the procedures previously described by Geisert et al. (1986). The PGF-2 $\alpha$ antiserum (gift from Dr K. T. Kirton, Upjohn Company, Kalamazoo, MI, U.S.A.) cross-reacted $<0 \cdot 1 \%$ with PGA, PGA-2, PGB, PGB-2, PGE-2, PGE-3; < $1 \%$ for $15-$ keto PGF-2 $\alpha$ and $8 \%$ for PGF- $1 \alpha$. Therefore, data are expressed as immunoreactive PGF. Sensitivity of the assay with respect to the standard curve was $25 \mathrm{pg}$. All samples were measured in a single assay which had an intra-assay coefficient of variation of $2 \cdot 9 \%$.

Oestradiol-17 $\beta$ analysis. Concentrations of oestradiol-17 $\beta$ in uterine flushings were determined by radioimmunoassay using procedures previously described by Hoagland \& Wettemann (1984). Sensitivity of the assay procedure was $2 \mathrm{pg} / \mathrm{ml}$. Intra- and inter-assay coefficients of variation were $24.9 \%$ and $18.0 \%$, respectively.

Plasmin inhibitor analysis. Plasmin inhibitor activity in uterine flushings was determined by using the ${ }^{125}$ I-labelled fibrin plate assay previously described by Fazleabas et al. (1983). A range of uterine protein concentrations was added at $4^{\circ} \mathrm{C}$ to previously prepared microtitre plates coated with ${ }^{125}$ I-labelled fibrin. A constant amount of activated plasminogen $(4 \mu \mathrm{g})$ was added and the plates were incubated at $37^{\circ} \mathrm{C}$ for $3 \mathrm{~h}$. Inhibition was determined by comparing the release of ${ }^{125} \mathrm{I}$ with control values of activated plasminogen run in the absence of inhibitor. One inhibitory unit (IU) was defined as the ability to inhibit one relative unit (RU) of enzyme activity. Validation of the assay procedure is described by Fazleabas et al. (1982).

Statistical analysis. Data were analysed by least squares analyses of variance using the General Linear Models procedures of the Statistical Analysis System (Barr et al., 1979). Orthogonal contrasts of means were made as follows: Group AC vs Group SE; Group AE vs Group AC and Group SE.

\section{Results}

The proportion of gilts which contained filamentous blastocysts after flushing the uterine horns on Day 14 was 4/4, 0/4 and 4/4 for Group AC, AE and SE, respectively. With the exception of one abnormal spherical blastocyst in a single gilt, embryos from gilts in Group AE failed to survive to Day 14 while filamentous blastocysts were present in all gilts in Groups AC and SE. The one spherical blastocyst flushed from the gilt in Group AE measured $20 \mathrm{~mm}$ in diameter which was classified as abnormal since pig blastocysts rapidly become tubular and filamentous after reaching $10 \mathrm{~mm}$ in diameter (Geisert et al., 1982b).

Least square means for total recoverable $\mathrm{Ca}^{2+}$, acid phosphatase and specific activity of acid phosphatase in uterine flushings are summarized in Ta'sle 1. While total protein values in uterine flushings were similar between treatment groups, oestrogen administration on Day 11 (Groups SE and AE) lowered total calcium $(P<0.02)$ and stimulated an increase $(P<0 \cdot 10)$ in total acid phosphatase activity in uterine flushings. Oestrogen treatment tended to increase specific acid phosphatase activity in uterine flushings to almost twice that measured in gilts in Group AC.

Total recoverable oestradiol, PGF and plasmin inhibitor content in uterine flushings are summarized in Table 2 . Oestradiol-17 $\beta$ content in uterine flushings was higher $(P<0 \cdot 10)$ in recipient gilts in Groups AC and SE, both of which contained intact filamentous blastocysts. In contrast, recipient gilts in Group $\mathrm{AE}$, in which embryos did not survive, had low levels of recoverable oestradiol-17ß. 
Table 1. Means for total calcium, protein, acid phosphatase activity and specific acid phosphatase activity in uterine flushings of recipient gilts treated with oestradiol valerate or vehicle on Day 11 of pregnancy

\begin{tabular}{lcccc}
\hline Group & $\begin{array}{c}\text { Calcium } \\
(\mathrm{mg})\end{array}$ & $\begin{array}{c}\text { Protein } \\
(\mathrm{mg})\end{array}$ & $\begin{array}{c}\text { Acid phosphatase } \\
\text { activity } \\
(\mu \mathrm{mol} \mathrm{Pi} / \mathrm{min})\end{array}$ & $\begin{array}{c}\text { Specific activity } \\
(\mu \mathrm{mol} \mathrm{Pi} / \mathrm{min} / \mathrm{mg} \text { protein })\end{array}$ \\
\hline $\mathrm{AC}$ & $0 \cdot 69^{\mathrm{a}}$ & 201 & $697^{\mathrm{c}}$ & 3.60 \\
$\mathrm{AE}$ & $0 \cdot 11^{\mathrm{b}}$ & 217 & $1256^{\mathrm{d}}$ & $6 \cdot 10$ \\
$\mathrm{SE}$ & $0 \cdot 00^{\mathrm{b}}$ & 261 & $1464^{\mathrm{d}}$ & $5 \cdot 90$ \\
Overall s.e.m. & $\pm 0 \cdot 10$ & \pm 29 & \pm 295 & \pm 1.8 \\
\hline
\end{tabular}

a.b Means not having a common superscript differ $(P<0.02)$.

${ }^{c, d}$ Means not having a common superscript differ $(P<0 \cdot 10)$.

Table 2. Means for total oestradiol, prostaglandin F and plasmin inhibitor activity in uterine flushings of recipient gilts treated with oestradiol valerate or vehicle on Day 11 of pregnancy

\begin{tabular}{lccc}
\hline Group & $\begin{array}{c}\text { Oestradiol } \\
(\mathrm{pg})\end{array}$ & $\begin{array}{c}\text { Prostaglandin F } \\
(\mathrm{ng})\end{array}$ & $\begin{array}{c}\text { Plasmin } \\
\text { inhibitor } \\
(\mathrm{IU})\end{array}$ \\
\hline $\mathrm{AC}$ & $2093^{\mathrm{a}, \mathrm{c}}$ & 198 & $56688^{\mathrm{d}}$ \\
$\mathrm{AE}$ & $280^{\mathrm{b}}$ & 180 & $333297^{\mathrm{c}}$ \\
$\mathrm{SE}$ & $899^{\mathrm{d}}$ & 361 & $44257^{\mathrm{d}}$ \\
s.e.m. & \pm 423 & \pm 177 & \pm 107131 \\
\hline
\end{tabular}

${ }^{\text {a.b }}$ Means in columns not having a common superscript differ $(P<0.01)$.

${ }^{\mathrm{c}, \mathrm{d}}$ Means in columns not having a common superscript differ $(P<0 \cdot 10)$.

Although no significant differences were found between the three treatment groups with respect to recoverable PGF, gilts in Group AE tended to have lower PGF levels, with the exception of one gilt in which concentrations of PGF were elevated.

Plasmin inhibitor levels were greater $(P<0 \cdot 10)$ in Group AE gilts compared to those in Groups SE and AC.

Two-dimensional electrophoresis of acidic and basic polypeptides in uterine flushings from different treatments showed similar qualitative polypeptide profiles. The polypeptides present were similar to those described by Basha et al. (1980).

\section{Discussion}

Pope et al. (1982) demonstrated that morphologically advanced blastocysts had a greater chance for survival than their less developed counterparts when transferred to the same uterine environment. This survival advantage may result from alteration of the uterine environment.

Geisert et al. (1982a) demonstrated that uterine glandular epithelial cells accumulate secretory vesicles until about Day 11 or 12 of pregnancy and that the contents of these vesicles are released during the period of blastocyst elongation and oestrogen production. A similar synchronized release of uterine histotrophe can be induced by administering exogenous oestrogen to cyclic gilts on Day 11 (Geisert et al., 1982c). Geisert et al. (1987) have indicated that endometrial sensitivity to 
oestrogen (shown by the ability to release calcium) does not occur until after Day 10 of the oestrous cycle.

The results from the present study demonstrate that oestradiol treatment on Day 11 advances uterine secretion with respect to calcium and acid phosphatase activity and that advancing uterine secretion in the presence of embryos that are $24 \mathrm{~h}$ behind in development (relative to their uterine environment) is embryocidal. Neither the degree of asynchrony between donor and recipient gilts nor the oestradiol treatment itself caused embryonic loss because viable filamentous blastocysts were recovered from Groups AC and SE.

In gilts of both groups, the recovery of oestradiol-17 $\beta$ was greater than from asynchronous oestradiol-treated gilts, indicating that blastocysts were synthetically active (Gadsby et al., 1980; Fischer et al., 1985). The recovery of less oestrogen from Group SE on Day 14 may reflect the normal declining synthesis in these older blastocysts after initial elongation (Zavy et al., 1980; Geisert et al., 1982a; Stone \& Seamark, 1985).

Prostaglandins F and E-2 increase in the uterine lumen of pregnant gilts on Day 12, coinciding with the period of rapid elongation and oestrogen production (Geisert et al., 1982a, 1986). In contrast, administration of exogenous oestrogen to cyclic gilts on Day $1 \cdot 1$ does not stimulate an increase in luminal PGF until about Day 15 (Frank et al., 1978). Therefore, although recoverable PGF content in asynchronous control and synchronous oestradiol-treated gilts containing viable blastocysts was not significantly greater than in asynchronous oestradiol-treated gilts, this may have been due to the recovery of an unexplained elevated amount of PGF from one gilt in Group AE. Nevertheless, it appeared that synthesis of PGF by blastocysts in Groups AC and SE was occurring normally.

Plasmin/trypsin inhibitors which are synthesized and released from the uterine luminal surface epithelium (Fazleabas et al., 1985) are thought to protect the uterine epithelial surface from proteases released by the conceptus during elongation and attachment, in particular, the protease plasminogen activator (Fazleabas et al., 1983). Gilts in Groups AC and SE had lower recoverable levels of plasmin inhibitor in the uterine flushings, perhaps because of the loss of inhibitor through its coating of blastocysts in these groups in contrast to the absence of embryos in Group AE gilts. Fazleabas et al. (1983) indicated that plasmin inhibitor does bind tightly to the trophoblastic membrane and several washings are required to remove it from blastocysts in culture.

It is apparent that early embryonic death may occur in the pig when blastocysts are presented to a uterine environment which has been advanced with oestrogen $24 \mathrm{~h}$ before they can undergo elongation. If blastocysts are left to develop at their own rate and allowed to stimulate the uterine environmental change at the onset of elongation, blastocyst development continues normally as demonstrated in the asynchronous control group. This would suggest that it is the blastocysts which regulate the time when appropriate changes occur in the uterine environment relative to their morphological development with the uterus serving a permissive role.

The failure of blastocysts to survive in asynchronous oestradiol-treated gilts may have been through either loss of their ability to undergo elongation, alteration in the uterine surface epithelium, or a direct embryocidal effect of the uterine environment.

The endometrial release of calcium into the uterine lumen becomes insensitive to additional stimulation with oestradiol after the initial elevation and decline of calcium on Day 12 (Geisert et al., 1982c). Although the role of calcium in the elongation process of the blastocyst is unclear, this ion is known to play a key role in several physiological responses including the release of secretory vesicles, activation of phospholipase $A_{2}$ (Rubin \& Laychock, 1978; Rasmussen \& Barrett, 1984), and regulating alterations in intracellular microfilaments.

In rats and mice, stage-specific proteins have been isolated from uterine fluids immediately before implantation (Aitken, 1977; Tzartos \& Surani, 1979) when there is, as observed in the pig, an alteration of the uterine environment. Embryos that are unable to respond to the altered uterine environment do not implant and are lost. The role of the endometrial proteins in regulating blastocyst development and elongation itself is known. It is possible that morphologically immature 
blastocysts may not possess receptors to recognize changes in regulatory proteins released by the endometrium or that are exposed on the uterine surface epithelium after oestrogen stimulation and therefore do not undergo developmental changes necessary for survival.

In conclusion, this study has defined a critical period in pig blastocyst development in which blastocysts are unable to survive an environment advanced with exogenous oestrogen treatment on Day 11. It is clear that blastocysts must attain a certain degree of morphological maturity before they can respond and survive in the altered uterine environment that is normally induced on Day 11 to 12 of pregnancy. In view of the wide variation in degree of morphological maturity between litter-mate embryos (Perry \& Rowlands, 1962; Anderson, 1978), the failure of immature embryos to survive the change in the intrauterine environment could account for a significant portion of early embryonic death in the pig.

Journal Article No 5048 of Agricultural Experiment Station, Oklahoma State University, Stillwater. We thank Dr K. T. Kirton (The Upjohn Company) for the PGF antiserum; Dr G. D. Niswender (Department of Physiology and Biophysics, Colorado State University, Fort Collins, Colorado) for the $17 \beta$-oestradiol-6 $\beta$-BSA antiserum; B. G. Biggers and M. W. Richards for surgical and technical assistance; and Eva Harrall and Kathy Frank for secretarial assistance. This material is based on work supported by the U.S. Department of Agriculture (Science and Education) under Agreement No. 86-CRCR-1-2105.

\section{References}

Aitken, R.J. (1977) Changes in the protein content of mouse uterine flushings during normal pregnancy and delayed implantation and after ovariectomy and oestradiol administration. J. Reprod. Fert. 50, 29-36.

Alexander, R.L. (1971) Evaluation of an automatic calcium titrator. Clin. Chem. 17, 1171-1175.

Anderson, L.L. (1978) Growth, protein content and distribution of early pig embryos. Anat. Rec. 190, $143-154$

Barr, A.J., Goodnight, J.H., Sall, J.P., Blair, W.H. \& Chilko, D.M. (1979) SAS User's Guide. SAS Institute Inc., Raleigh, N.C.

Basha, S.M.M., Bazer, F.W. \& Roberts, R.M. (1979) The secretion of a uterine-specific purple phosphatase by cultured explants of porcine endometrium. Dependency upon the state of pregnancy of the donor animal. Biol. Reprod. 20, 431-441.

Basha, S.M.M., Bazer, F.W., Geisert, R.D. \& Roberts, R.M. (1980) Progesterone-induced uterine secretions in pigs. Recovery from pseudopregnant and unilaterally pregnant gilts. J. Anim. Sci. 50, 113-123.

Fazleabas, A.T., Bazer, F.W. \& Roberts, R.M. (1982) Purification and properties of a progesteroneinduced plasmin/trypsin inhibitor from uterine secretions of pigs and its immunocytochemical localization in the pregnant uterus. J. biol. Chem. 256, 6886-6897.

Fazleabas, A.T., Geisert, R.D., Bazer, F.W. \& Roberts, R.M. (1983) Relationship between release of plasminogen activator and estrogen by blastocysts and secretion of plasmin inhibitor by uterine endometrium in the pregnant pig. Biol. Reprod. 29, $225-238$.

Fazleabas, A.T., Bazer, F.W., Hansen, P.J., Geisert, R.D. \& Roberts, R.M. (1985) Differential patterns of secretory protein localization within the pig uterine endometrium. Endocrinology 116, 240-245.
Fischer, H.E., Bazer, F.W. \& Fields, M.J. (1985) Steroid metabolism by endometrial and conceptus tissues during early pregnancy and pseudopregnancy in gilts. J. Reprod. Fert. 75, 69-78.

Frank, M., Bazer, F.W., Thatcher, W.W. \& Wilcox, C.J. (1978) A study of prostaglandin $F_{2} \alpha$ as the luteolysin in swine. IV. An explanation for the luteotrophic effect of estradiol. Prostaglandins 15, 151-159.

Gadsby, J.E., Heap, R.B. \& Burton, R.D. (1980) Oestrogen production by blastocyst and early embryonic tissue of various species. J. Reprod. Fert. 60, 409-417.

Geisert, R.D., Renegar, R.H., Thatcher, W.W., Roberts, R.M. \& Bazer, F.W. (1982a) Establishment of pregnancy in the pig. I. Interrelationships between preimplantation development of the pig blastocyst and uterine endometrial secretions. Biol. Reprod. 27, 925-939.

Geisert, R.D., Brookbank, J.W., Roberts, R.M. \& Bazer, F.W. (1982b) Establishment of pregnancy in the pig. II. Cellular remodelling of the porcine blastocysts during elongation on day 12 of pregnancy. Biol. Reprod. 27, 941-955.

Geisert, R.D., Thatcher, W.W., Roberts, R.M. \& Bazer, F.W. (1982c) Establishment of pregnancy in the pig: III. Endometrial secretory response to estradiol valerate administered on day 11 of the estrous cycle. Biol. Reprod. 27, 957-965.

Geisert, R.D., Rasby, R.J., Minton, J.E. \& Wettemann, R.P. (1986) Role of prostaglandins in development of porcine blastocysts. Prostaglandins. 31, 191-204.

Geisert, R.D., Zavy, M.T., Wettemann, R.P. \& Biggers, B.G. (1987) Length of pseudopregnancy and pattern of uterine protein release as influenced by time and duration of oestrogen administration in the pig. $J$. Reprod. Fert. 79, 163-172.

Godkin, J.D., Bazer, F.W., Lewis, G.S., Geisert, R.D. \& Roberts, R.M. (1982) Synthesis and release of poly- 
peptides by pig conceptuses during the period of blastocyst elongation and attachment. Biol. Reprod. 27, 977-987.

Hoagland, T.A. \& Wettemann, R.P. (1984) Influence of elevated ambient temperature after breeding on plasma corticoids, estradiol and progesterone in gilts. Theriogenology 22, 15-24.

Lowry, O.H., Rosebrough, N.J., Farr, A.L. \& Randall, R.J. (1951) Protein measurement with folin phenol reagent. J. biol. Chem. 193, 265-275.

Perry, J.S. \& Rowlands, I.W. (1962) Early pregnancy in the pig. J. Reprod. Fert. 4, 175-188.

Polge, C. (1982) Embryo transplantation and preservation. In Control of Pig Reproduction, pp. 277-291. Eds D. J. A. Cole \& G. R. Foxcroft. Butterworth Scientific, London.

Pope, W.F. \& First, N.L. (1985) Factors affecting the survival of pig embryos. Theriogenology 23, 91-105.

Pope, W.F., Maurer, R.R. \& Stormshak, F. (1982) Survival of porcine embryos after asynchronous transfer. Proc. Soc. exp. Biol. Med. 171, 179-183.

Rasmussen, H. \& Barrett, P.Q. (1984) Calcium messenger system: an integrated view. Physiol. Rev. 64, 938-984.

Rowson, L.E.A. \& Moor, R.M. (1966) Embryo transfer in the sheep: the significance of synchronizing oestrus in the donor and recipient animal. J. Reprod. Fert. 11, 207-212.
Rowson, L.E.A., Moor, R.M. \& Lawson, R.A.S. (1969) Fertility following egg transfer in the cow: effect of method, medium and synchronization of oestrus. $J$. Reprod. Fert. 18, 517-523.

Rubin, R.P. \& Laychock, S.G. (1978) Prostaglandins and calcium-membrane interactions in secretory glands. Ann. N.Y. Acad. Sci. 307, 377-390.

Stone, B.A. \& Seamark, R.F. (1985) Steroid hormones in uterine washings and in plasma of gilts between Days 9 and 15 after oestrus and between Days 9 and 15 after coitus. J. Reprod. Fert. 75, 209-221.

Tzartos, S.J. \& Surani, M.A.H. (1979) Affinity of uterine luminal proteins for rat blastocysts. J. Reprod. Fert. 56, 579-586.

Wilmut, I., Sales, D.I. \& Ashworth, C.J. (1985) The influence of variation in embryo stage and maternal hormone profiles on embryo survival in farm animals. Theriogenology 23, 107-119.

Zavy, M.T., Bazer, F.W., Thatcher, W.W. \& Wilcox, C.J. (1980) A study of prostaglandin $F_{2} \alpha$ as the luteolysin in swine: V. Comparison of prostaglandin $\mathrm{F}$, progestin, oestrone and oestradiol in uterine flushings from pregnant and nonpregnant gilts. Prostaglandins 20, 837-851.

Received 1 August 1986 